support exhibitions, publications, films and other means of disseminating information (no figures for expenditure, however, are given in the Broadsheet).

For the rest, the Broadsheet concludes that British standards in housing are still high in comparison with those of France, but are being overtaken by those of West Germany. In numbers of dwellings built in recent years (until 1964) Britain has been lagging. Her present need is to step up new building schedules, particularly of dwellings to let, and to demolish and replace slums. Housing policy in Britain has been confused by indecision as to whether the provision, of houses should be regarded as a social service, or as a commercial operation. The existence of subsidized and also non-profit housing has almost completely stopped the investment of private capital in dwellings for letting.

While it is proper that local authorities should have the major responsibilities for housing families of all incomelevels, it may be argued that subsidies should be reserved for those families that, because of age, lack of earning capacity, or other handicaps, are unable to afford economic rents. In both France and Western Germany the policy is to grant housing allowances to such families and the consequences of adopting such a system in Britain should be explored. In Britain the National Assistance Board pays out rent allowances to 1.5 million families that are eligible for assistance, but the policy elsewhere is to make a clear distinction between housing allowances and public assistance. It is desirable also to diversify the means by which houses for letting at economic rents should be provided : the recently created Housing Corporation should be given every support in its encouragement of cost-rent and ownership societies. There seems to be no point in deterring the private sector from competing in this field.

Adoption of long-term planning policies would enable those engaged in producing dwellings to plan ahead and to concentrate on their work without fear of too frequent change. It is impossible to ignore the success of the German housing problem and the extent to which this is attributable to long-term policies. The efforts of Western Germany to influence the supply and price of building land have not always been fully rewarded, but have achieved some part of their object. Ways and means whereby the British Government could exert an adequate influence have received intensive study, and action is now urgently required. If tax concessions are to be given to some form of saving, like those of Trustee Savings Banks, it is arguable that equivalent concessions should be awarded to Building Societies, the efforts of which are directed exclusively to providing finance for housing. The psychological and material effects of such measures have been clearly demonstrated in Western Germany by the successful revival of the saving habit. Encouragement should be given to the house-building part of the construction industry to rationalize its organization, cut out restrictive practices, intensify training and make the best possible use of the skills and knowledge of its management and work people. The possibility of further curtailment of the apprenticeship period with more intensive training and training on actual work is worth considering. Consideration might also be given to whether it is politic to allow public, commercial and industrial building to outstrip the building of dwellings. Experience in Germany and France suggests that self-building societies, which in a small way have done useful work, could be more vigorously encouraged in Britain.

The Broadsheet considers that the trained personnel of the British building industry are probably of as high a calibre as, if not higher than, their counterpart in other countries, and to perform the task that confronts them they need only the leadership, guidance and encouragement that vigorous Government backing can provide.

\title{
INSPECTION OF ALKALI, ETC., WORKS
}

$\mathrm{T}$ HE one hundred and first annual report on alkali, etc., works in England and Wales, prepared by the Chief Inspector*, covers the year 1964. It stresses the co-operation of industry with the Inspectorate without which, individually by works, and collectively through research associations, and the like, the task of the Inspectorate would be much more onerous. Certainly without this co-operation the Inspectorate would have to be multiplied several times in size and a department would be needed for specialized techniques of waste gas sampling and analysis, as well as for developing control measures for air pollution. The number of works registered under the Act at the end of the year was 1,995, involving the operation of 3,208 processes, and 11,966 visits and inspections were paid during the year, compared with 10,850 in 1963, including 123 special visits by the Chief and Deputy Chief Inspectors. Of this total, 231 were to, or in connexion with, works not registered under the Act, 46 were concerned with control of radioactive emissions and 37 were to, or in connexion with, colliery spoilbanks. During the inspections 4,563 quantitative analyses were made of gases ovolved from processes in operation, compared with 3,433 in 1963 , while 746 special samples, compared with 615 in 1963, were taken and submitted to the Government Chemist.

The report also emphasizes the effect of the changing face of industry on the task and responsibilities of the inspectorate; a searching and realistic appraisal of the responsibilities and day-to-day activities of the inspectorate has been made. A historical and technical review of the decline and fall of the traditional sulphuric acid

* Ministry of Housing and Local Government-Scottish Development Department. One Hundred and First Annual Report on Alkali, etc., Works by the Chief Inspectors, 1964. Pp. iv +76. (London: H.M.S.O., 1965.) $5 s$. $6 d$. net. lead chamber process and one of the early days of the copper industry are included.

In the belief that most new contact sulphuric acid plants will burn sulphur of high quality as the raw material, tables have been prepared giving the stack heights for final discharge of waste gases from units or clusters of units making daily $200-2,000$ tons of monohydrate. If different raw materials are used it will be a simple matter for inspectors and industry to calculate appropriate chimney heights using the information given and to apply it to the particular permitted loss of sulphur burned. Reference is again made to mist emission from certain contact sulphuric acid plants, and while our knowledge of the reasons for this is still obscure the problem receives the close attention of the Inspectorate (some progress appears to have been made).

The Chief Inspector, under "Alkali, etc., Works and Regulations (Scotland) Acts, 1906 and 1951", records that at Decomber $31,1964,263$ works were registered under the 1906 Act, and 361 processes were inspected within these works. 622 visits were paid by the Inspectorate on work under the Act or in the interest of preventing air pollution, of which 420 were to premises registered under the Act of 1906.

Further experimental testing of emissions of dust from registered premises was carried out on behalf of the Inspectorate by the two-man team provided on contract by the Department of Scientific and Industrial Research. Thirteen works were covered in 41 visits, and 87 tests were made mostly at the electricity power stations. In general, inspections showed that the provisions of the Act were observed in good spirit as well as with attention to the tests. 